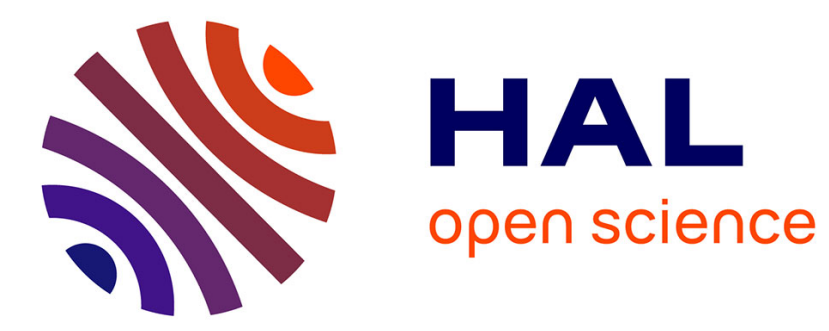

\title{
Experimental investigation of the blade/seal interaction
}

Sarah Baïz, Jacky Fabis, Xavier Boidin, Yannick Desplanques

\section{To cite this version:}

Sarah Baïz, Jacky Fabis, Xavier Boidin, Yannick Desplanques. Experimental investigation of the blade/seal interaction. Proceedings of the Institution of Mechanical Engineers, Part J: Journal of Engineering Tribology, 2013, 227 (9), pp.980-995. 10.1177/1350650112472853 . hal-00863616

\section{HAL Id: hal-00863616 https://hal.science/hal-00863616}

Submitted on 7 Jun 2017

HAL is a multi-disciplinary open access archive for the deposit and dissemination of scientific research documents, whether they are published or not. The documents may come from teaching and research institutions in France or abroad, or from public or private research centers.
L'archive ouverte pluridisciplinaire HAL, est destinée au dépôt et à la diffusion de documents scientifiques de niveau recherche, publiés ou non, émanant des établissements d'enseignement et de recherche français ou étrangers, des laboratoires publics ou privés. 


\title{
Experimental investigation of the bladel seal interaction
}

\author{
Sarah Baïz 1,2,3,4, Jacky Fabis', Xavier Boidin' ${ }^{2,3,4}$ and \\ Yannick Desplanques, 2,3
}

\begin{abstract}
The use of dynamic seals to reduce the rotor/stator dynamic clearance in jet engine compressor stages leads to a higher rubbing occurrence between each blade and the coated inside of the casing. This article describes the development of a test rig capable to investigate forces and wear at the dynamic blade/seal interaction, in conjunction with blade kinetics. Testing conditions are consistent with those of low-pressure compressor stages of jet engines: high-speed rubbing occurs between a TA6V blade substitute and an aluminium-silicon/boron nitride abradable seal. The platform is instrumented to allow a dynamic measurement of forces and displacements as well as high-speed imaging of the blade/seal interaction zone throughout the experiment. The experiments showed that the blade incursion speed and penetration depth in the abradable seal both affect the amplitude and frequency of blade vibration. The amount and severity of blade incursions into the abradable seal have an impact on seal wear type and intensity, which can in turn increase blade excitation.
\end{abstract}

\section{Keywords}

Abradable, rig, friction, wear, seal, impact, vibration

\section{Introduction}

Abradable seals are used in aeronautical compressors and turbines as a way to increase the jet engine efficiency and safety by limiting leakage flows occurring in the gap located between rotating blade tips and stationary parts. ${ }^{1}$ But smaller dynamic clearances lead to more frequent blade/casing interactions. ${ }^{2}$ Therefore, abradable seals are empirically designed not only to withstand the in-service environmental conditions but also to dislocate when penetrated by the tips of rotor blades. ${ }^{3}$

The abradable seal considered in this study is of the aluminium-silicon/boron nitride (Al-Si/hBN) family, which is a seal used in low compressor stages of most recent engines, ${ }^{4}$ in particular the $\mathrm{Al}-8 \mathrm{Si}-20 \mathrm{hBN}$ grade, or Metco 320NS. Microstructure of this abradable material is shown in Figure 1. This grade has a higher corrosion resistance than the Al-Si/Polyester Metco 601 seal that it replaces. ${ }^{5,6}$ The plasma thermal spraying deposition technique is used to produce a 2-4 $\mathrm{mm}$ abradable seal on the inside casing wall, thereby reducing the rotor/stator gap to a few hundreds of micrometers. ${ }^{7}$ Rigidity of the $\mathrm{Al}-\mathrm{Si} / \mathrm{hBN}$ metallic matrix and a high amount of porosity - up to $30 \%$ for the $\mathrm{Al}-8 \mathrm{Si}-20 \mathrm{hBN}$ type ${ }^{8}$ - are the result of a compromise. The seal has to be abradable by a TA6V compressor blade, and have a good resistance to erosion and oxidation, both crucial requirements in first stages compressors. ${ }^{9}$
The boron nitride ( $\mathrm{hBN}$ ) component of the abradable material is a solid lubricant, whose role is to minimise friction and heating during blade/seal contact. ${ }^{10}$ However, blade/seal rubbing can cause premature seal wear and/or blade damage have been reported and flagged as causes for engine failure. ${ }^{11}$

This study focuses on getting dynamic measurements of blade kinetics and loading at the blade/seal interaction, in conjunction with abradable wear. Emphasis is put on testing conditions that are consistent with those of low-pressure compressor stages of jet engines.

\section{State-of-the-art}

\section{Key parameters}

A few laboratory and industrial test rigs have been developed to quantify heating and/or wear after

\footnotetext{
'Department of Aeroelasticity and Structural Dynamics, French Aerospace Lab, France

${ }^{2}$ Univ Lille Nord de France, France

${ }^{3}$ Department of Mechanical Engineering, Ecole Centrale de Lille, Laboratoire de Mécanique de Lille, France

${ }^{4}$ CNRS, UMR 8I07, France

\section{Corresponding author:}

Sarah Baïz, Department of Mechanical Engineering, Ecole Centrale de Lille, Cité Scientifique, BP 48, 5965I Villeneuve d'Ascq, France.

Email: Baizsarah@aol.com
} 


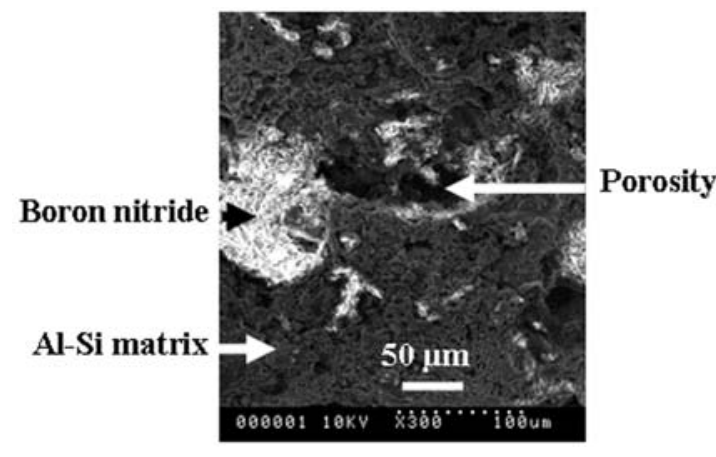

Figure I. Metco 320NS abradable seal microstructure (SEM secondary electron image).

SEM: scanning electron microscopy.

rubbing of a small incurved abradable coated segment against a rigid blade at in-service sliding speed and incursion rate. Experiments focusing low compressor stages of the engine have pointed out the influential parameters and ranges, ${ }^{7,12,13}$ including:

(a) blade/seal relative sliding speed: $100-300 \mathrm{~m} / \mathrm{s}$;

(b) depth of blade incursion in the abradable seal: 50-700 $\mu \mathrm{m}$; and

(c) speed of incursion: $2-800 \mu \mathrm{m} / \mathrm{s}$.

An incursion of $1 \mathrm{~mm}$ represents a severe incursion in actual in-service conditions. A $2 \mathrm{~mm}$ wear depth of the abradable seal in the compressor can lead to engine failure as it increases the risk of a surge. ${ }^{11}$ The different values tested were set less than these extreme and accidental values, within the 50-700 $\mu \mathrm{m}$ incursion range defined in the literature, ${ }^{13}$ using the piezoelectric actuator. Also, testing should be performed at in-service stage temperature, i.e. 300$500^{\circ} \mathrm{C}$, because it can affect the blade and seal material behaviour and, therefore, lead to different wear mechanisms than those observed at room temperature. $^{14,15}$

\section{Hardness testing}

To compare abradable seals without having to resort to rig testing, industrials widely rely on the HR15Y superficial Rockwell hardness test. HR15Y measurements are simple and obtained through a normalised procedure. ${ }^{16}$ Moreover, the measured penetration depths have showed a fair experimental correlation to the abradability test results of the Sulzer Metco rig. ${ }^{17}$ This indicates a correlation between seal wear and plastic deformation ability of the abradable material under normal compression. More recently, it has been demonstrated that performing the scratch test can provide an even more reliable indication of the overall mechanical performance of abradable seals because it includes tangential loading in the experiment. ${ }^{18}$ Depending on the amount of compressive loading and the tangential sliding speed, $\mathrm{Al}-\mathrm{Si} / \mathrm{hBN}$ seals experienced either densification ahead of the indenter or brittle fracture. ${ }^{19}$ However, neither hardness nor scratch testing can characterise the wear and forces during blade/seal rubs at a high relative sliding speed.

\section{Abradable wear}

Abradable wear mechanisms have been experimentally characterised on wear rigs. The mechanisms relevant to the plasma-sprayed porous abradable seals are: cutting (abrasion), plastic deformation, transfer and fusion. ${ }^{20}$ Dominance conditions of any of these mechanisms are typically plotted on a wear map, allowing wear prediction for non-tested values of relative blade/seal penetration and speed..$^{21,22}$

On the existing rigs, loading at the blade/seal interaction is not yet characterised at a representative blade/seal relative interaction speed. Rig experiments have been performed at up to $100 \mathrm{~m} / \mathrm{s}$ relative tangential speed, but the interaction configuration was simplified into the orthogonal cutting component and the blade replaced by a rigid tool. From 50 to $500 \mu \mathrm{m}$ penetration depths of the blade into the seal, the interaction force increased with the blade/seal relative sliding speed and penetration depth. It has been observed that wear was created by brittle separation of the fine abradable particles during the tool/seal interaction, following a cutting-type mechanism. ${ }^{23}$ This observation is consistent with the elastic brittle behaviour showed by Al-8Si-20hBN seals under static single axe tensile loading, with typical ultimate tensile strain of $20 \mathrm{MPa}$ and less than $0.3 \%$ relative elongation. $^{24}$

However, little to no experimental data available in the literature is able to describe the case where the rubs are occurring between a sacrificial seal and a tool that is similarly flexible to a blade, as schematised in Figure 2(a). Simulation tools should incorporate models that account for seal behaviour and wear as well as its possible dynamic coupling with blade vibration. Therefore, there is much need for experimental data that can allow a better understanding of the dynamic interaction between an abradable seal and a flexible blade. For this purpose, a dedicated test rig was developed at the ONERA institute of Lille (France), in collaboration with the laboratories of Laboratoire de Mécanique de Lille and Ecole Centrale de Lille, and the first results are reported in this article.

\section{Development of the test rig}

\section{Overview of requirements}

Our experimental approach is based on the design of a simplified blade/seal interaction setup and geometry that allows loading and speed testing conditions to be 

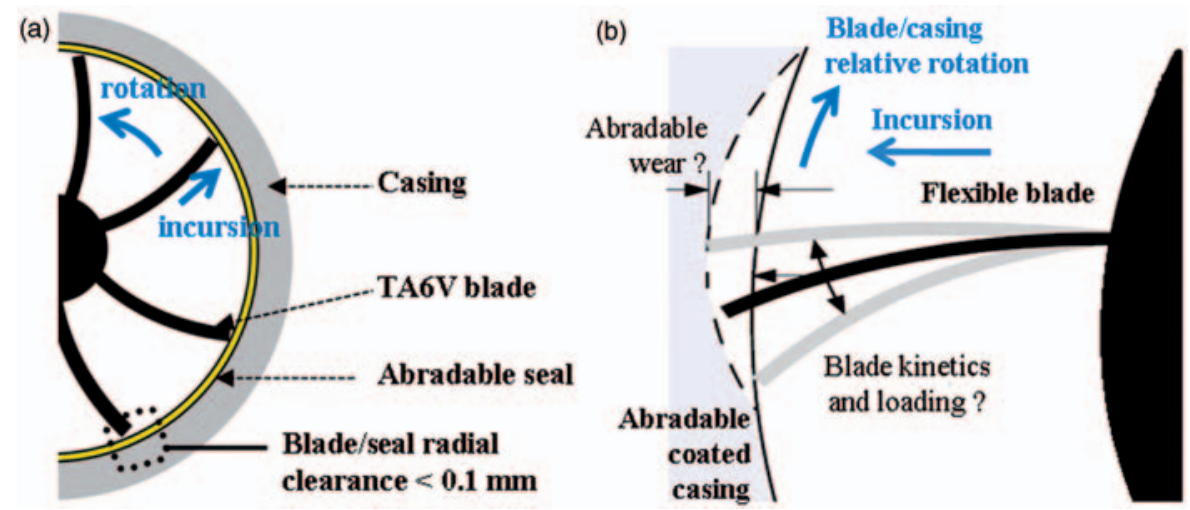

Figure 2. Schematic blade/seal interaction: (a) engine compressor stage configuration and (b) schematic dynamic coupling that can occur at the interaction between a flexible blade and a sacrificial seal.

close to those encountered in-service in the first compressor stages. Experiments were designed to be easier to equip for accurate measurements than the testing of a full-scale compressor stage. The objective is to provide insightful data and information pertaining to conditions that are detrimental to engine performance, such as accelerated seal wear or blade rupturing. Accidental scenarii are suspected to result from coupling phenomena occurring at the blade/seal interaction. Figure 2(b) shows how frequency and severity of blade/seal rubs can be related with seal wear and vibration of the flexible blade.

\section{Approach}

In order to investigate the phenomena occurring at the dynamic interaction between a flexible blade and a sacrificial seal, the test rig has a blade/seal system composed of (Figure 3):

(a) a substitute blade: a flexible tool movable towards the abradable surface with a chosen depth and speed of incursion and

(b) an abradable seal: an abradable-coated solid cylinder of $300 \mathrm{~mm}$ diameter, motorised to rotate around its axis.

The ability to rub a flexible tool on part or whole of the coated surface of the cylinder circumference is already a main improvement to the existing test rigs. The drawback of the chosen contact configuration (Figure 3) is that motion is opposite to that of a coated inside of a compressor casing (Figure 2(a)). This solution has nevertheless several advantages in terms of enabling of dynamic couplings, wear evaluation and monitoring of local loading and kinetics at the blade/seal interaction. As shown in Figure 4, the non-rotating blade and the non-mobile blade/seal interaction zone can be fully equipped with standard dynamic instrumentation and filmed by a high-speed camera.

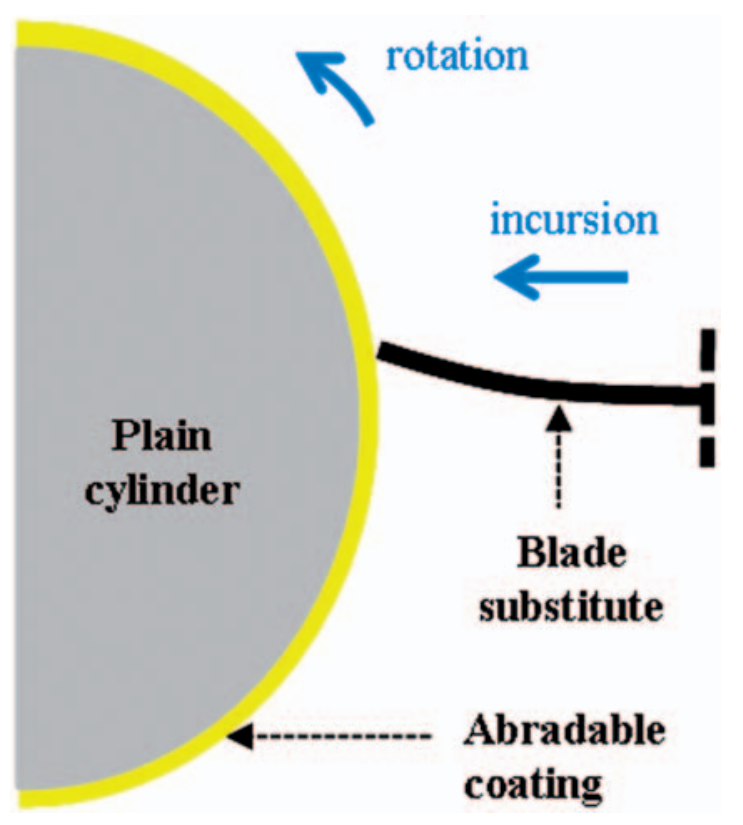

Figure 3. Schematic blade/seal interaction configuration on the test rig.

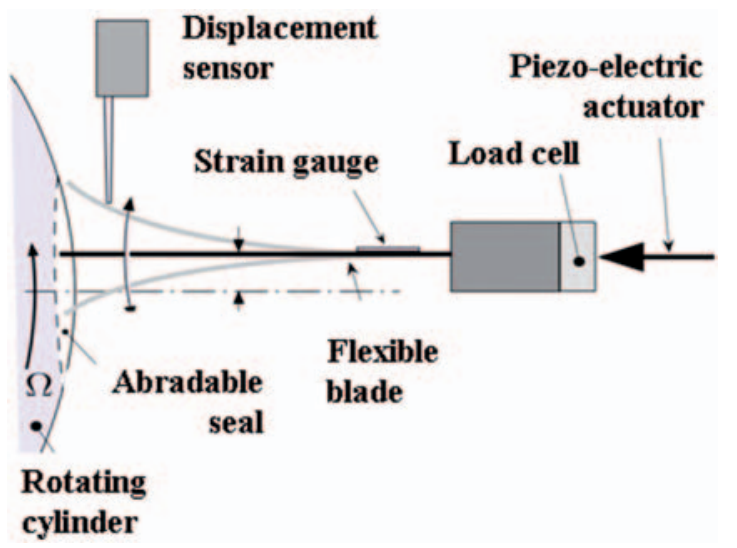

Figure 4. Control and monitoring of a blade/seal interaction on the test rig. 


\section{Design of the incursion cell}

Figure 5 shows the computer-aided design of the blade/seal interaction zone.

The blade substitute is end-restraint on a small rigid unit and mounted on the displacement axis of an elliptical piezoelectric actuator. The actuator can, therefore, produce precise and quick incursions of the blade towards the abradable seal, and create back and forth displacement if needed. The fixation side of the ellipse actuator is fastened to a rigid cleat attached to a larger unit. The small rigid unit carrying the blade is mounted on bendable legs in order to ensure motion without any tangential loading of the actuator. The small rigid unit and its legs constitute the incursion cell'. These legs are fixed on the larger rigid unit, which carries the whole incursion cell and is guided on rails to allow coarse positioning of the blade tip in front of the coated surface.

At any given rotational speed of the coated cylinder, this actuator can bring the blade in the trajectory of the seal and back, once per rotation, at up to $50 \mathrm{~mm} / \mathrm{s}$ incursion speed provided that motion amplitude is less than $500 \mu \mathrm{m}$. To minimise the initial blade/ seal spacing, the blade tip is placed tangent to the coated surface before starting the experiment.

\section{Design of the abradable seal}

For the abradable surface of the cylinder to offer several independent testing tracks, the cylinder track is $130 \mathrm{~mm}$ wide. It provides 10 testing tracks of $10 \mathrm{~mm}$ width (blade width), spaced from one another by $2.5 \mathrm{~mm}$ tracks. Also, a high abradable seal thickness was produced to allow post-mortem sampling for microstructure characterisation after testing.

Deposition of an Al-8Si-20hBN (Metco320NS) abradable seal was done on the external surface of a cylinder made of 2024 aluminium alloy, whose thermal dilation coefficient is similar to that of the Al-8Si-hBN $\left(24 \times 10^{-6} \mathrm{~K}^{-1}\right)$. Thermal-spray deposition was performed at LERMPS (UTBM, France)

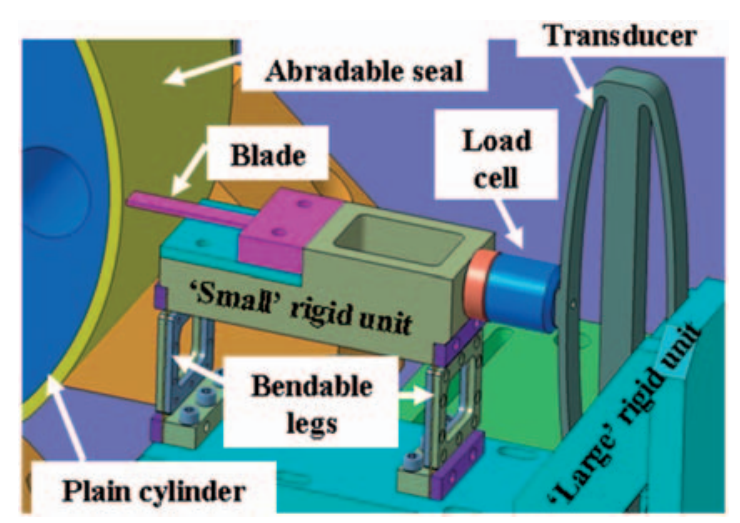

Figure 5. Incursion cell. following the Sulzer Metco recommendations for F4MB-type plasma spray gun and Twin20-type power feeder and Argon Hydrogen parameters. ${ }^{5}$ To ensure proper adhesion of the seal, the substrate was cleaned with alcohol, blasted with white F60 corundum at 2.5 bars and coated with a $400 \mu \mathrm{m}$ AMDRY956 (95Ni-5Al) layer before spraying.

The $6 \mathrm{~mm}$ thick abradable layer produced was machined down to a $5 \mathrm{~mm}$ thickness using a diamond tool, and a G2.5 dynamic balancing of the coated cylinder mounted on its shaft was performed using a SCHENCK H40BU machine. The resulting possible displacement of the mass centre-off of the cylinder revolution axis is less than $4 \mu \mathrm{m}$ at $6000 \mathrm{r} / \mathrm{min}$.

The rig is equipped with a $1.5 \mathrm{~kW}$ induction motor capable of bringing the coated cylinder up to a $6000 \mathrm{r} / \mathrm{min}$ rotational speed, i.e. $100 \mathrm{~m} / \mathrm{s}$ tangential speed at the seal periphery. The rotor shaft is placed between two SKF bearings so that any dynamic unbalances created during the experiment can be instantly corrected, and to ensure a higher precision in rotation guiding. The cylinder is protected by a shielded housing that is bolted to an infinitely rigid frame incased in a containment room, from the outside of which experiments can be safely launched and monitored.

\section{Rig instrumentation}

Instrumentation of the rig aims at characterising the dynamic blade/seal interaction. It comprises a load cell, a strain gauge, three displacement sensors and a high-speed camera. Characteristics and experimental settings of the sensors are detailed hereafter.

A strain gauge (TML FLA2). Bonded to the top face of the blade at a distance of $5 \mathrm{~mm}$ from the restraint end (Figure 6), the gauge is calibrated to measure the dynamic tangential strain of the blade. The VISHAY 2310 conditioning unit (with $75 \mathrm{kHz}$ wideband) is put in quarter three-wire bridge configuration in order to account for line resistance. The excitation voltage is set at $3.5 \mathrm{~V}$ to avoid thermal drifts and

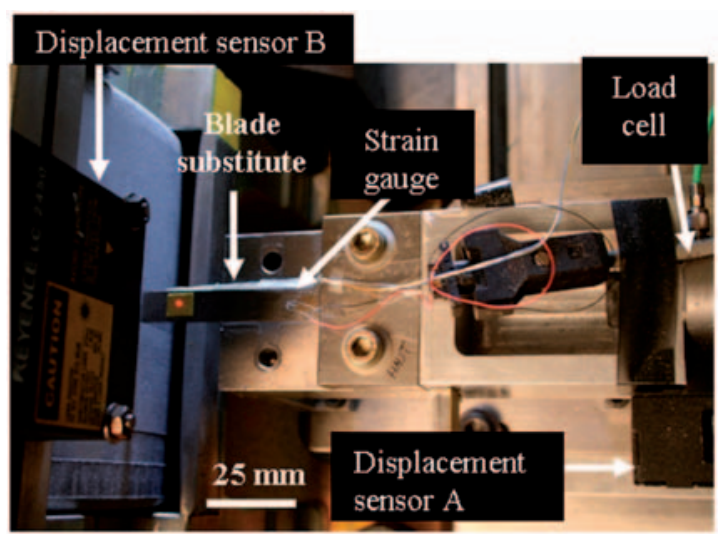

Figure 6. Top-view of the blade instrumentation. 
compensate for the very low dissipative capacity of the small-sized gauge grid. The output signal conditioning is set on wideband mode, with a $75 \mathrm{kHz}$ lowpass frequency.

A piezoelectric load cell (KISTLER 903IA). Inserted between the free mobile end of the elliptical actuator and the small unit carrying the blade (Figure 5), the load cell measures blade loading along its axis. It thus records the contribution to the dynamic blade/seal interaction force that is normal to the abradable surface. The measurement, therefore, includes a contribution of the actuator's dynamic stiffness. The load cell has a high rigidity of $6 \mathrm{kN} / \mu \mathrm{m}$ and a free-load natural frequency brought from 80 to $10 \mathrm{kHz}$ after the adjunction of an aluminium support plate. The output signal is amplified and filtered by a KISTLER 5007 unit, at a $180 \mathrm{kHz}$ cut-off low-pass frequency. The pre-loaded cell is able to measure compressive as well as tensile forces. Prior to testing, force calibration was performed throughout the measuring range (up to $300 \mathrm{~N}$ ), with the load sensor being inserted in the incursion unit in the experiment-type configuration. For this purpose, an INSTRON 4302 compression machine equipped with a 0.5 class (EN 10002-2) load cell was used.

Three laser displacement sensors (two KEYENCE LC2400 sensors and one LKG82 sensor). One sensor - labelled sensor ' $A$ ' in Figure 6 - is placed behind the incursion cell in order to measure the blade normal translation towards the seal. The second sensor - labelled sensor ' $\mathrm{B}$ ' in Figure 6 - is located above the blade and captures its deflection amplitude. In order to prevent abradable debris to invade the sensor's observation field, the cylinder's direction of rotation is set to allow the major part of the abradable particles liberated at the blade/seal interaction to evacuate below the blade. The third displacement sensor - labelled sensor ' $C$ ' - faces the cylinder track on which the experiment is performed, at $180^{\circ}$ from the interaction zone, in order to monitor the dynamic profile of the abradable seal throughout the experiment, with the objective to quantify the depth and distribution of wear along the blade's rubbing path. These three displacement sensors are characterised by a $50 \mu \mathrm{m}$ spot diameter, a $20 \mu$ s integration time, a $0.5 \mu \mathrm{m}$ resolution and a measuring range $\pm 8 \mathrm{~mm}$.

An optical tachymeter. Facing one track of the cylinder, it records the time of passage of a small target that has been bonded on this particular track. The raw output signal is used to calculate the mean speed of the seal periphery during the few milliseconds of blade/seal interaction.

A high-speed camera (VISARIO). The camera is placed laterally to the blade/seal interaction zone so that it can capture most of the blade tip movements such as

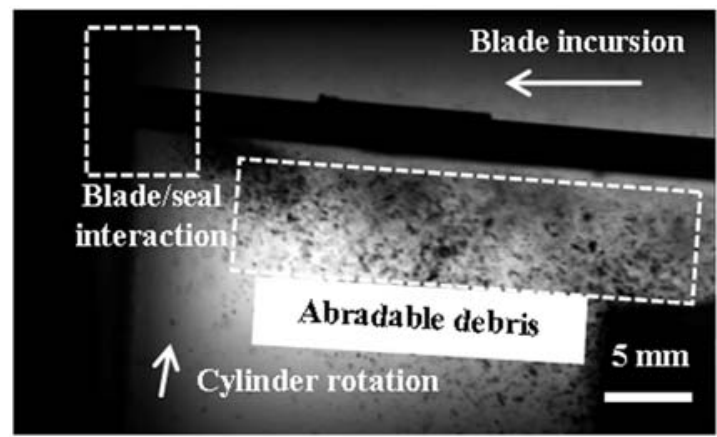

Figure 7. Blade/seal interaction image captured by the highspeed camera.

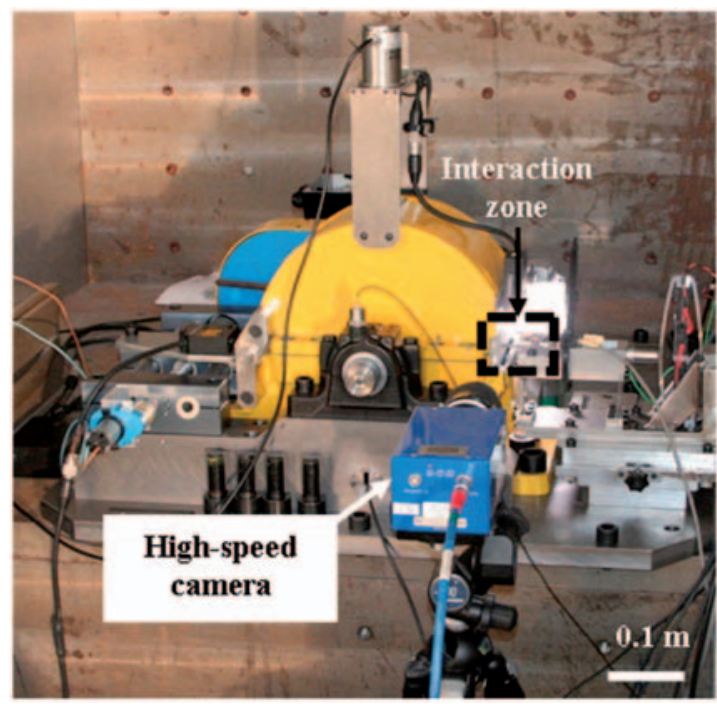

Figure 8. Test rig.

translation, rubbing, bouncing and vibration, during each experiment (Figure 7). With a resolution of $1536 \times 1024$ pixels, this camera is able to take 1000 frames per second and its integration time can be lowered to $10 \mu \mathrm{s}$. In order to capture up to 4000 frames per second, the resolution was lowered to $768 \times 512$ pixels, and shadow images obtained by placing a cold light HMI (halogen metal iodide) projector behind the experiment (Figure 8).

A data logger (NICOLET MULTIPRO). Given the extremely short duration of the blade/seal interaction experiments, it was highly critical that data acquisition be robust and of high resolution. The data logger used is a NICOLET MULTIPRO multi-channels highresolution transient analyser, equipped with MP120E cards of 1 Mega sample per second storage capacity each, with 12 bits dynamics.

\section{Data analysis methodology}

For each experiment, the measurements are analysed using the methodology described in this section. 
Measured and calculated parameters are presented in Tables 1 and 2, and illustrated in Figure 9.

\section{Testing parameters}

Blade characteristics. Three TA6V blades were produced and are described in Table 3. Each blade's dynamic characteristics - generalised mass, stiffness and vibration frequency - were analytically determined using the model for bending vibrations of Euler-Bernouilli beams, for modes up to the third, considering free-bending vibrations with clampedfree boundary conditions. Thickness and length of each blade substitute were adjusted to allow easier comparison between their first vibration mode and that of a fourth stage compressor blade. Experiment 1 analysed hereafter was performed using blade ' $a$ '.

Blade incursion depth and speed. Each blade/seal interaction experiment should occur within the duration of one rotation or less so that wear rubs do not superimpose on one another. As specified in Table 4, the APA 750XL actuator allows a $50 \mathrm{~mm} / \mathrm{s}$ incursion speed for $0.5 \mathrm{~mm}$ incursion strokes and less than $15 \mathrm{~mm} / \mathrm{s}$ incursion speed for $1 \mathrm{~mm}$ strokes. Therefore, the coated cylinder's rotation duration should be at least $50 \mathrm{~ms}$, which requires a rotational speed lower than $1200 \mathrm{r} / \mathrm{min}$, i.e. less than $20 \mathrm{~m} / \mathrm{s}$ speed at the seal periphery. Experiment 1 was carried out at a $20 \mathrm{~m} / \mathrm{s}$ tangential speed at the seal periphery, a $170 \mu \mathrm{m}$ blade incursion depth and a $400 \mathrm{~mm} / \mathrm{s}$ blade incursion speed.

\section{Experimental protocol}

First, the large rigid unit shown in Figure 5 is adjusted to position the blade tip tangent - with no contact - to one of the cylinder's virgin abradable tracks. The cylinder's rotation around its axis is then launched. When the $1200 \mathrm{r} / \mathrm{min}$ target speed is reached, the actuator triggers blade displacement in the direction normal to the seal surface and towards it with a chosen amplitude and speed of incursion. Each experiment was designed to create, within the $50 \mathrm{~ms}$ duration of one cylinder rotation, a full blade/seal interaction: displacement of the blade in and out of the seal's trajectory a single or several times, with a chosen rubbing duration.

\section{Estimation of blade tangential loading}

As represented in Figure 10, the amplitudes and frequencies of blade deflection $D_{T}$, are used to quantify blade kinetics. Blade strain $\varepsilon$ is presented unfiltered, and indicates the blade's dynamic tangential loading.

In all experiments, $\varepsilon$ was largely in phase with $D_{T}$, which is an indication that the blade's first vibration mode was dominant. While free-blade vibrations occurred as expected at the blade's

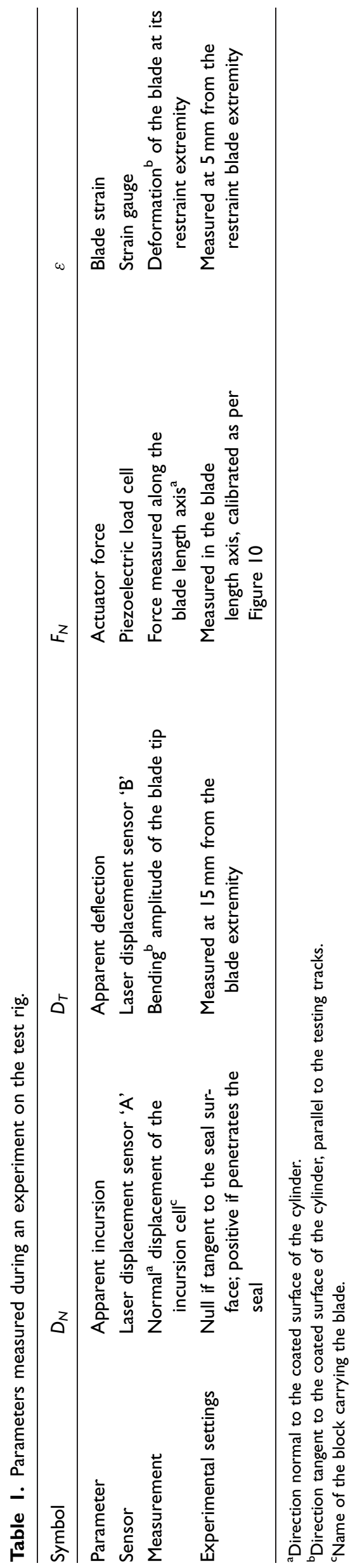


Table 2. Parameters estimated using the raw measurements.

\begin{tabular}{lll}
\hline Parameter & Variable estimated & Estimation method \\
\hline$t_{\text {tot }}$ & Duration of the blade/seal interaction & Incursion time in $D_{N}$ \\
$V_{N}$ & Apparent incursion speed of the blade tip & Positive slope in $D_{N}$ \\
$V_{P}$ & Tangential speed at the abradable track periphery & Rotation duration \\
$D_{N}^{\max }$ & Apparent blade incursion & Maximum of $D_{N}$ during $\Delta t_{\text {tot }}$ \\
$D_{T}^{\max }$ & Blade deflection & Maximum of $D_{T}$ during $\Delta t_{\text {tot }}$ \\
$f_{N}$ & Normal vibration frequency of the incursion cell & Mean frequency of $D_{N}$ during the free blade tip vibration \\
$f_{T}$ & Blade bouncing frequency on the seal & Mean contact initiation frequency in $D_{T}$ during $\Delta t_{\text {tot }}$ \\
\hline
\end{tabular}

Table 3. Characteristics of the tested blade substitutes (free bending vibration with clamped-free boundary conditions).

\begin{tabular}{|c|c|c|c|c|}
\hline Blade substitutes characteristics & & Blade a & Blade $b$ & Blade c \\
\hline \multirow{3}{*}{ Effective dimensions (mm) } & Thickness & 2 & 1.2 & 1.2 \\
\hline & Length & 60 & 60 & 45 \\
\hline & Width & 10 & 10 & 10 \\
\hline \multirow[t]{3}{*}{ Generalised mass $(\mathrm{g})$} & Mode I & 9.9 & 5.9 & 4.4 \\
\hline & Mode 2 & 5.1 & 3.1 & 2.3 \\
\hline & Mode 3 & 5.3 & 3.2 & 2.4 \\
\hline \multirow[t]{3}{*}{ Generalised dynamic stiffness (N/mm) } & Mode I & 78 & 17 & 40 \\
\hline & Mode 2 & 1589 & 343 & 814 \\
\hline & Mode 3 & 12,940 & 2795 & 6625 \\
\hline \multirow[t]{3}{*}{ Vibration frequency $(\mathrm{Hz})$} & $f_{\mathrm{I}}$ & 450 & 270 & 480 \\
\hline & $f_{2}$ & 2800 & 1680 & 2990 \\
\hline & $f_{3}$ & 7845 & 4705 & 8370 \\
\hline
\end{tabular}

Table 4. Performances of the APA $750 X L$ piezoelectric actuator.

\begin{tabular}{lll}
\hline Tested parameters & $\begin{array}{l}\text { Manufacturer } \\
\text { data }^{\mathrm{a}}\end{array}$ & $\begin{array}{l}\text { Measured } \\
\text { values }^{\mathrm{b}}\end{array}$ \\
\hline Stiffness $(\mathrm{N} / \mu \mathrm{m})$ & 1.7 & 0.8 \\
Natural frequency $(\mathrm{Hz})$ & 320 & 220 \\
Blockage force $(\mathrm{N})$ & 1250 & 980 \\
Maximal displacement & $750 \mu \mathrm{m}$ & $500 \mu \mathrm{m}$ at $100 \mathrm{~Hz}$ \\
& & $1050 \mu \mathrm{m}$ at $\mathrm{I5} \mathrm{Hz}$ \\
\hline
\end{tabular}

${ }^{\mathrm{a}}$ The APA 750XL actuator is manufactured by CEDRAT Recherche. ${ }^{b}$ Open-loop tests using a TEKTRONIC FG507 signal generator and a KEPCO BOP200IM amplifier (IIOW, I A).

natural frequency $f_{1}$, the frequency $f_{T}$ associated with blade vibration during the blade/seal interaction is found to be higher than $f_{1}$ - about four times in experiment 1 . Blade deflection reached $2.8 \mathrm{~mm}$ in this experiment, and the vibration amplitude was $\pm 1.3 \mathrm{~mm}$.

\section{Estimation of blade normal loading}

Upon its motion by the piezoelectric actuator, the incursion cell - tagged 'small rigid unit' in Figure 5 - vibrated in the normal direction. These vibrations

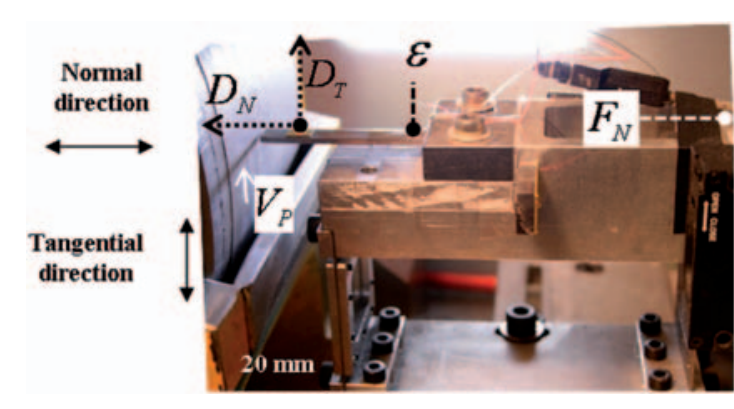

Figure 9. Measurement parameters during each experiment.

are the ones visible on the normal measurements of blade displacement $D_{N}$ and force $F_{N}$ outside the blade/seal interaction timeframe $\Delta t_{\text {tot }}$. As expected, the associated vibration frequencies depended on the mass of the incursion cell, as well as speed and depth of incursion. As a result of this lack of rigidity of the incursion cell in the normal direction, actuator force amplitudes were below $100 \mathrm{~N}$ in all the experiments.

\section{Evaluation of seal wear}

In experiment 1 , the incursion settings led to a blade/ seal interaction composed of blade/seal contact 


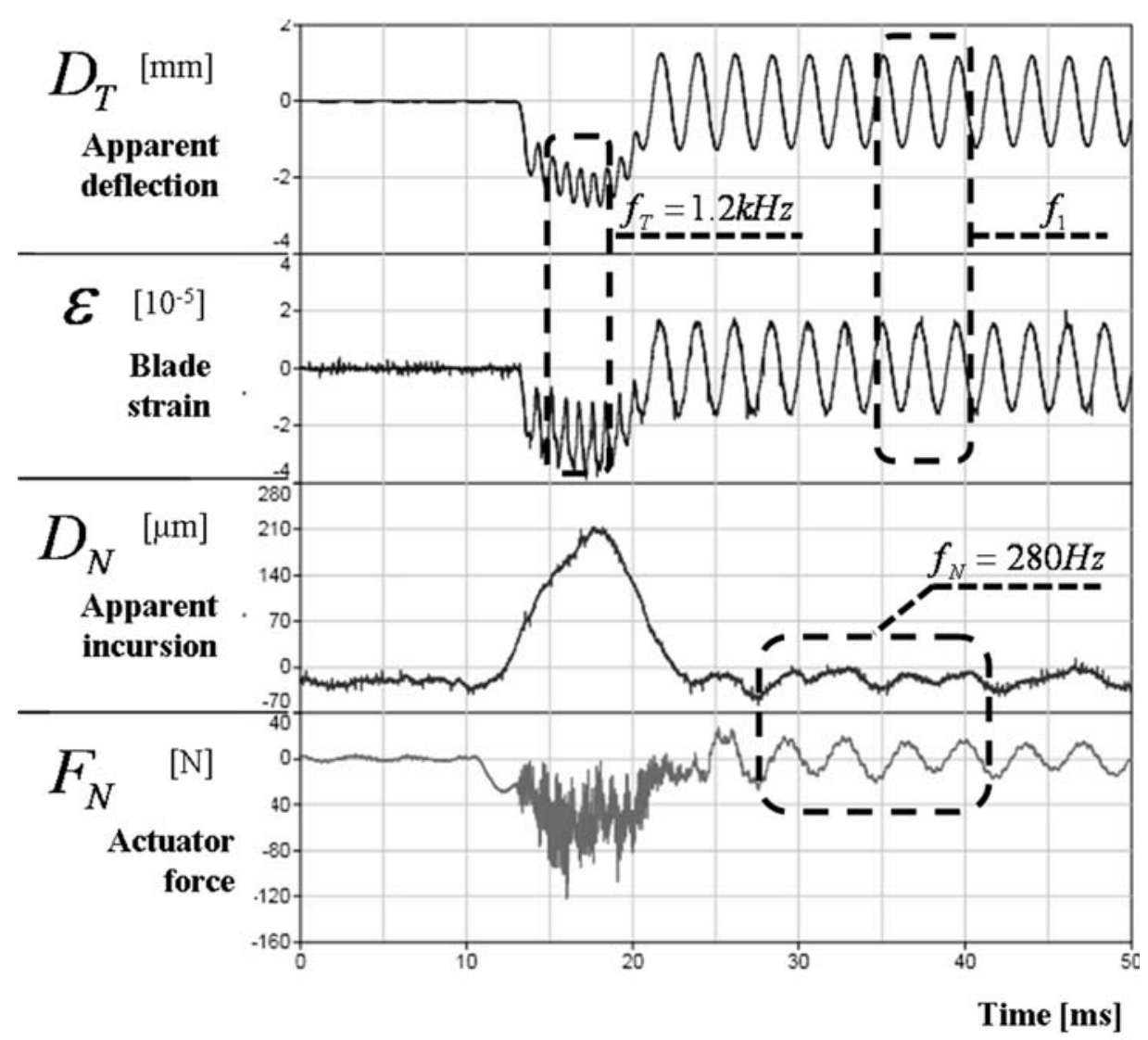

Figure 10. Raw data (experiment I).

initiation, blade bending, followed by several alternated rubbing and bouncing episodes of the blade on the abradable material coating of the rotating cylinder. Figure 11 shows the abradable profile measurements before and after the experiment captured by the laser displacement sensor ' $C$ '. Depth and spatial distribution of the wear marks due to blade bounces is not evident from these measurements. Therefore, blade deflection $D_{T}$ readings were used in conjunction with blade strain $\varepsilon$ readings to evaluate the number of blade bounces on the abradable surface. A simple visual inspection of the track surface (Figure 12) made it possible to check the number of wear marks for most experiments, as the rubbed zones of abradable material are shinier than the virgin ones due to the dissemination of the solid lubricant $\mathrm{hBN}$ upon friction.

When rubbing occurs over a longer portion of the track, or when it is harder to differentiate the rubbed track portion from the virgin one, additional lowspeed profile measurement before and after testing are recommended. Sampling and microscopic imaging of the rubbed seal surface would also provide an estimation of the wear rub dimensions. The objective is to analyse wear type and intensity in conjunction with blade loading under different incursion settings.

\section{Comparative analysis of experiments}

In order to examine the influence of testing parameters and investigate the existence of dynamics couplings at the blade/seal interaction, raw signals of eight experiments are here analysed and compared to one another, following the methodology presented in the previous section.

\section{Experimental settings for the eight experiments}

The various incursion settings are described in Tables 5 and 6 and the raw measurements of interest are plotted in Figures 13 to 20. Excerpts of high-speed video of the interaction zone during the experiments are provided in Figures 21 and 22. In experiments 1 to 4 , blade 'a' was tested on independent virgin tracks. For experiment 5 , the track was voluntarily damaged by repeated wear marks before performing the experiment. The cylinder rotational speed is equal to $1200 \mathrm{r} / \mathrm{min}$ for all experiments except number 7 , for which it is half.

\section{Influence of blade characteristics}

It is important to note that incursion pre-settings were affected by the blade's response. Experiments 4, 6 and 8 had the same actuator settings of depth and speed of 


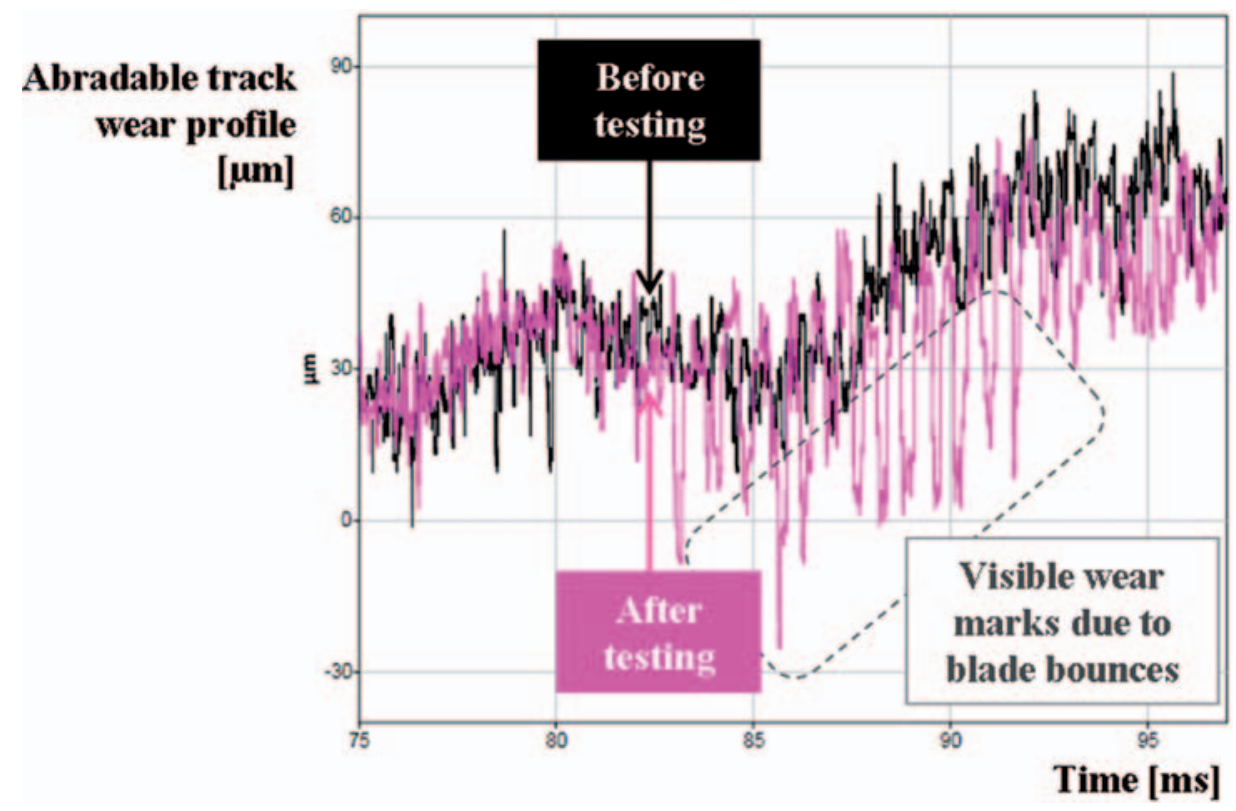

Figure II. Track wear profile before and after testing.

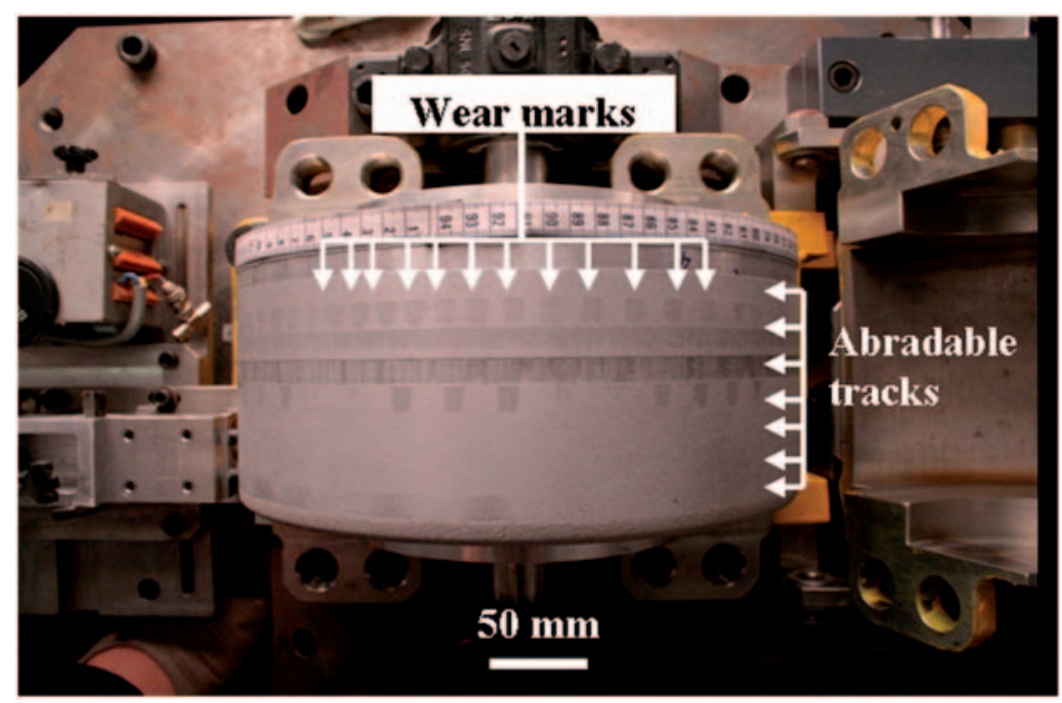

Figure 12. Cylinder surface after some experiments.

Table 5. Experimental conditions.

\begin{tabular}{lllll}
\hline $\begin{array}{l}\text { Experiment } \\
\text { number }\end{array}$ & $\begin{array}{l}\text { Abradable } \\
\text { track }\end{array}$ & $\begin{array}{l}V_{P} \\
(\mathrm{~m} / \mathrm{s})\end{array}$ & Blade $^{\mathrm{a}}$ & $\begin{array}{l}\text { Incursion } \\
\text { type }\end{array}$ \\
\hline 1 & Virgin & 19 & $\mathrm{a}$ & Single \\
2 & & & & \\
3 & & & & Multiple (4) \\
4 & & & & Single \\
5 & Worn & & & Multiple (3 to 4) \\
6 & Virgin & & $\mathrm{b}$ & \\
7 & & 10 & & \\
8 & & 19 & $\mathrm{c}$ & \\
\hline
\end{tabular}

${ }^{\text {a }}$ See Table 3 for blade characteristics. apparent incursion, but the apparent incursion $D_{N}$ or the apparent incursion speed $V_{N}$ differed from the settings, depending if blade thickness was 2 or $1.2 \mathrm{~mm}$.

As expected, increasing blade stiffness and natural frequency decreases its ability to bend when touching the seal. Experiments 6 (blade 'b') and 8 (blade 'c') illustrate this point: despite the same experimental settings, blade deflection upon first contact with the seal was different -3.6 and $3.1 \mathrm{~mm}$, respectively.

\section{Influence of apparent incursion}

It was found that the depth of blade incursion had an influence on blade deflection during the interaction. 
Table 6. Experimental measurements (apparent blade incursion and vibration).

\begin{tabular}{lllllll}
\hline Experiment number & tot $(\mathrm{ms})$ & $V_{N}(\mathrm{~mm} / \mathrm{s})$ & $f_{N}(\mathrm{~Hz})$ & $D_{N}^{\max }(\mu \mathrm{m})$ & $D_{T}^{\max }(\mathrm{mm})$ & $f_{T}(\mathrm{~Hz})$ \\
\hline 1 & 8.5 & 40 & 280 & 170 & 2.7 & 1200 \\
2 & 19 & & 140 & 380 & 3.9 & 1600 \\
3 & 35 & 16 & & 280 & 3 & $\mathrm{~N} / \mathrm{A}^{\mathrm{a}}$ \\
4 & 25 & 40 & & 110 & 3.5 & 900 \\
5 & 35 & 18 & & 350 & 6.1 & 1000 \\
6 & 25 & 60 & & & 3.6 & 900 \\
7 & & & & & 3.1 & 1200 \\
8 & & & & & & \\
\hline
\end{tabular}

${ }^{\text {a }}$ The blade bends when touching the seal, then makes a continuous rub.

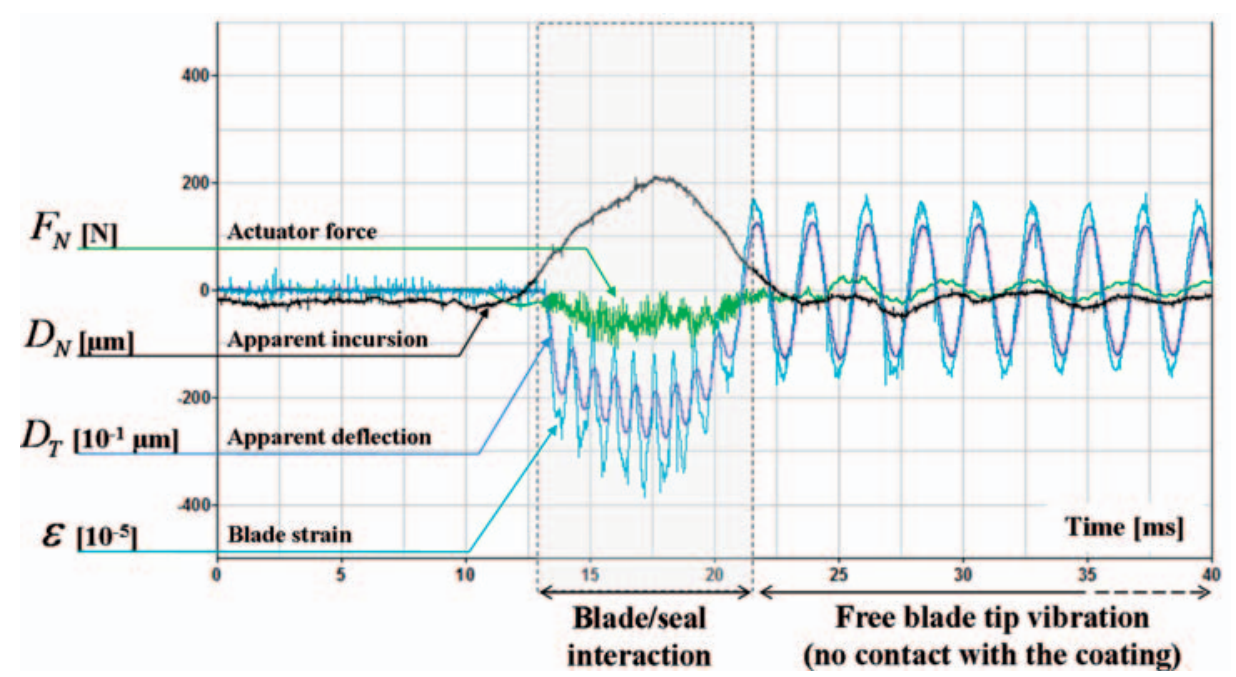

Figure 13. Experiment I (blade a; $V_{P}=19 \mathrm{~m} / \mathrm{s} ; D_{N}^{\max }=170 \mu \mathrm{m}$; and $V_{N}=40 \mathrm{~mm} / \mathrm{s}$ ) measurements.

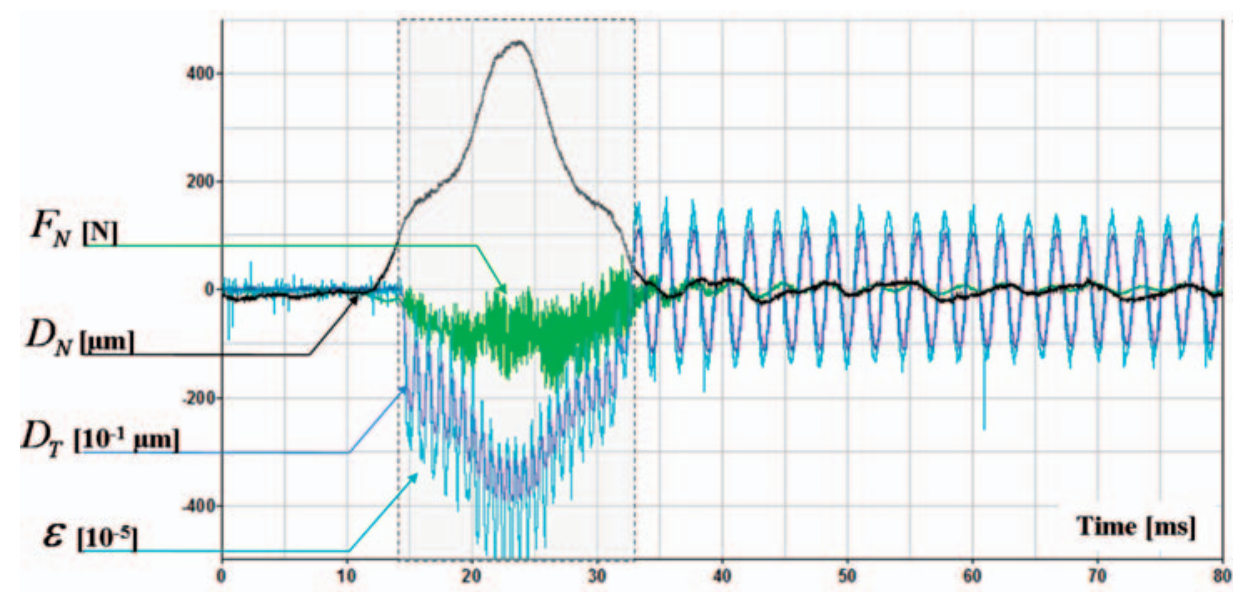

Figure 14. Experiment 2 (blade a; $V_{P}=19 \mathrm{~m} / \mathrm{s} ; D_{N}^{\max }=380 \mu \mathrm{m}$; and $V_{N}=40 \mathrm{~mm} / \mathrm{s}$ ) measurements.

This finding is consistent with results obtained on an orthogonal cutting test rig equipped with a rigid blade: ${ }^{24}$ a higher incursion depth in the abradable seal led to a higher interaction force. Experiment 2 $\left(V_{N}=40 \mathrm{~mm} / \mathrm{s} ; \quad D_{N}^{\max }=380 \mu \mathrm{m}\right) \quad$ had the same apparent incursion speed as experiment 1 $\left(V_{N}=40 \mathrm{~mm} / \mathrm{s} ; D_{N}^{\max }=170 \mu \mathrm{m}\right)$ but a larger incursion depth, and it resulted in a larger blade first deflection amplitude $\quad\left(D_{T}^{\max }=2.7 \mathrm{~mm}\right.$ for experiment 1 ; $D_{T}^{\max }=3.9 \mathrm{~mm}$ for experiment 2) and a larger blade 


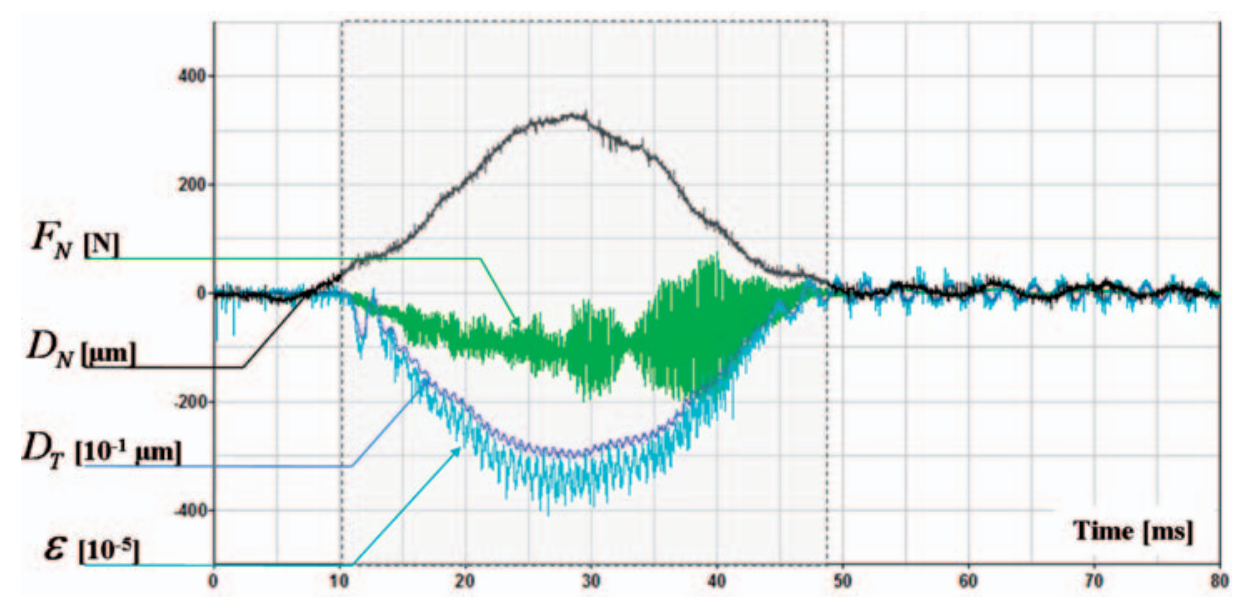

Figure 15. Experiment 3 (blade a; $V_{P}=19 \mathrm{~m} / \mathrm{s} ; D_{N}^{\max }=280 \mu \mathrm{m}$; and $V_{N}=16 \mathrm{~mm} / \mathrm{s}$ ) measurements.

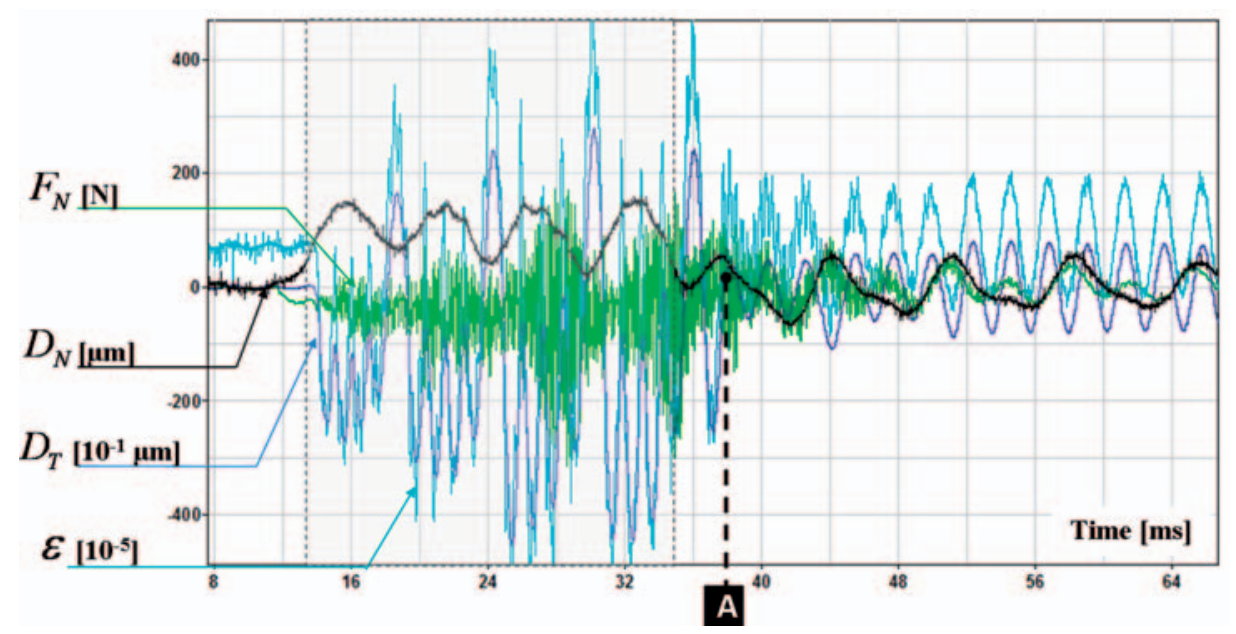

Figure 16. Experiment 4 (blade a; $V_{P}=19 \mathrm{~m} / \mathrm{s} ; D_{N}^{\max }=110 \mu \mathrm{m}$; and $V_{N}=40 \mathrm{~mm} / \mathrm{s}$ ) measurements.

bouncing frequency during the interaction $\left(f_{T}=1.2 \mathrm{kHz}\right.$ for experiment $1 ; f_{T}=1.6 \mathrm{kHz}$ for experiment 2). Also, the higher blade excitation in experiment 2 resulted in a higher number of rub marks (23 for experiment 2; 8 for experiment 1 ).

\section{Influence of apparent incursion speed}

Performed at a lower apparent incursion speed and depth than experiment $2\left(V_{N}=40 \mathrm{~mm} / \mathrm{s} ; D_{N}^{\max }=\right.$ $380 \mu \mathrm{m})$, experiment $3\left(V_{N}=16 \mathrm{~mm} / \mathrm{s} ; D_{N}^{\max }=280 \mu \mathrm{m}\right)$ did not show the multiple blade bounces and rubbing episodes seen in experiment 2. Instead, the blade bent when it touched the seal and underwent continuous friction with the seal until it was removed from its trajectory. Also, lower apparent speed and depth of incursion led to a lower blade deflection upon first blade/seal contact $\left(D_{T}^{\max }=3.9 \mathrm{~mm}\right.$ in experiment $2 ; D_{T}^{\max }=3 \mathrm{~mm}$ in experiment 3 ), which is preferable for the blade's integrity.

\section{Influence of the number of incursions}

It was found that imposing a higher number of incursions during the blade/seal interaction had an impact on initial blade deflection: four successive incursions in experiment 4 led to a higher blade tangential loading $\left(D_{T}^{\max }=4.5 \mathrm{~mm}\right)$ than experiment $1\left(D_{T}^{\max }=\right.$ $2.7 \mathrm{~mm}$ ) which was a single-incursion test.

\section{Influence of seal wear}

Experiments 3 and 5 have similar incursion settings $\left(V_{N}=20 \mathrm{~mm} / \mathrm{s} ; D_{N}^{\max }=300 \mu \mathrm{m}\right)$ but different initial track wear status. It was found that performing the experiment on a previously worn seal (experiment 5 , Figure 17) instead of on a virgin track (experiment 4, Figure 16) led to an increase in both blade excitation amplitude and frequency: on a virgin track, blade deflection $D_{T}^{\max }$ was equal to $3 \mathrm{~mm}$ and the rub was continuous, whereas on a worn track, $D_{T}^{\max }$ was equal 
to $6.1 \mathrm{~mm}$ and the blade bounced at a frequency $f_{T}=1 \mathrm{kHz}$. Blade excitation increased with track wear in a similar way that it increased with the number of blade incursions.

\section{Influence of tangential speed at the coated cylinder's periphery}

A lower tangential speed $\left(V_{P}=19 \mathrm{~m} / \mathrm{s}\right.$ in experiment 6; $V_{P}=10 \mathrm{~m} / \mathrm{s}$ in experiment 7) results logically in a lower blade deflection $\left(D_{T}^{\max }=3.6 \mathrm{~mm}\right.$ in experiment $6 ; D_{T}^{\max }=3.1 \mathrm{~mm}$ in experiment 7 ), without having an influence on the blade bounce frequency $\left(f_{T}=900 \mathrm{~Hz}\right.$ for both experiments).

\section{Dynamic coupling at the blade/seal interaction}

In some cases, the blade touched the seal as it was being moved back outside of the coated cylinder trajectory. Immediately consecutive to such blade/seal contacts, the blade's vibration frequency changed, in two possible ways, 'A' or ' $\mathrm{B}$ ' as spotted in Figures 16 to 20 :

1. Type ' $A$ ' coupling seen in experiments 4 and 7 (Figures 16 and 19): as a result of a blade/seal contact for which the blade deflection was opposite in direction to the seal's tangential speed, blade vibration amplitude decreased - from 2 to $0.8 \mathrm{~mm}$ in experiment 4 - or stayed the same $-1.2 \mathrm{~mm}$ in experiment 7 .

2. Type ' $\mathrm{B}$ ' coupling seen in experiments 6 to 8 (Figures 18 to 20): as a result of a blade/seal contact for which the blade deflection was in the same direction as the seal's tangential speed, blade vibration amplitude increased by $35 \%$ - from 0.5 to $1.5 \mathrm{~mm}$ in experiment 6 ; from 1.1 to $3 \mathrm{~mm}$ in experiment 7; and from 1.2 to $3.1 \mathrm{~mm}$ in experiment 8 .

Such observations were confirmed using the highspeed videos of the experiments.

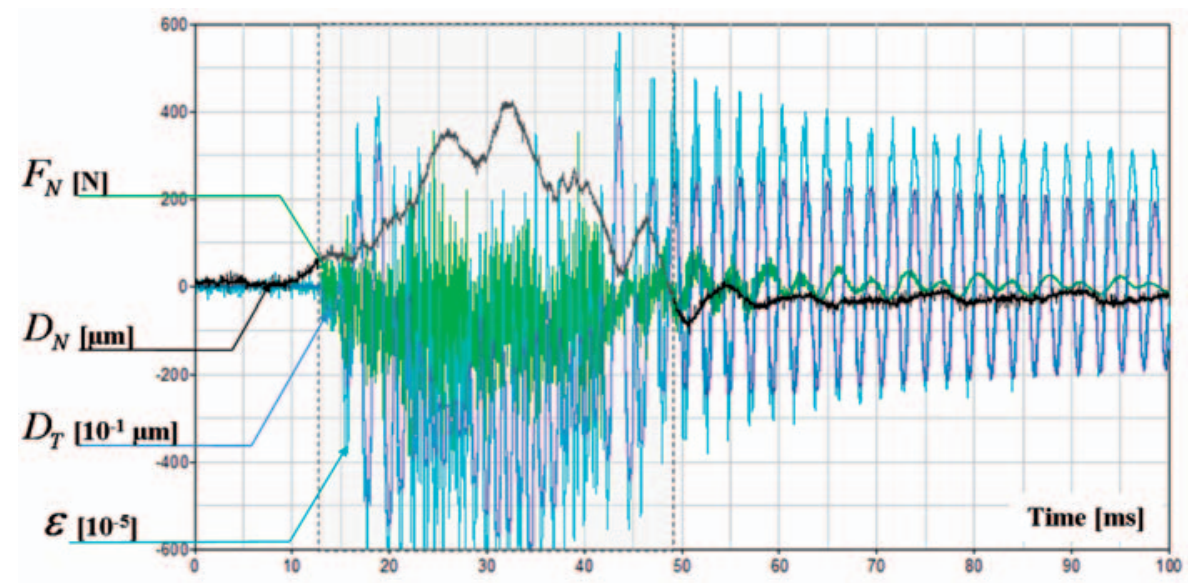

Figure 17. Experiment 5 (blade a; $V_{P}=19 \mathrm{~m} / \mathrm{s} ; D_{N}^{\max }=350 \mu \mathrm{m}$; and $V_{N}=18 \mathrm{~mm} / \mathrm{s}$ ) measurements.

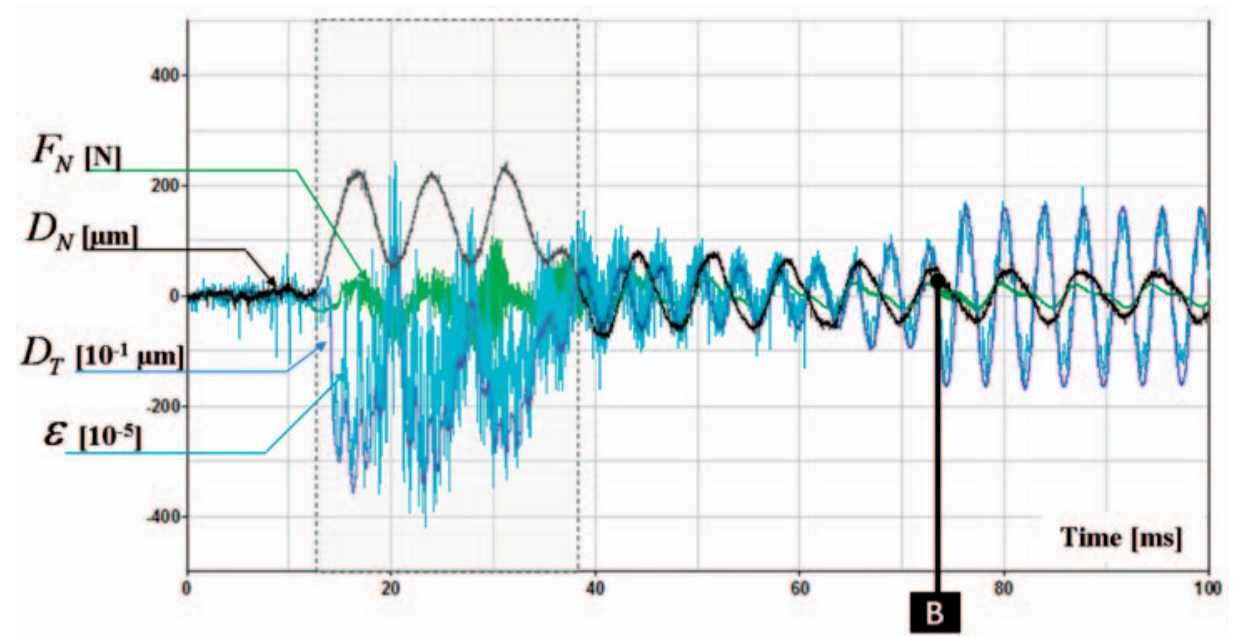

Figure 18. Experiment 6 (blade b; $V_{P}=19 \mathrm{~m} / \mathrm{s} ; D_{N}^{\max }=200 \mu \mathrm{m}$; and $V_{N}=60 \mathrm{~mm} / \mathrm{s}$ ) measurements. 


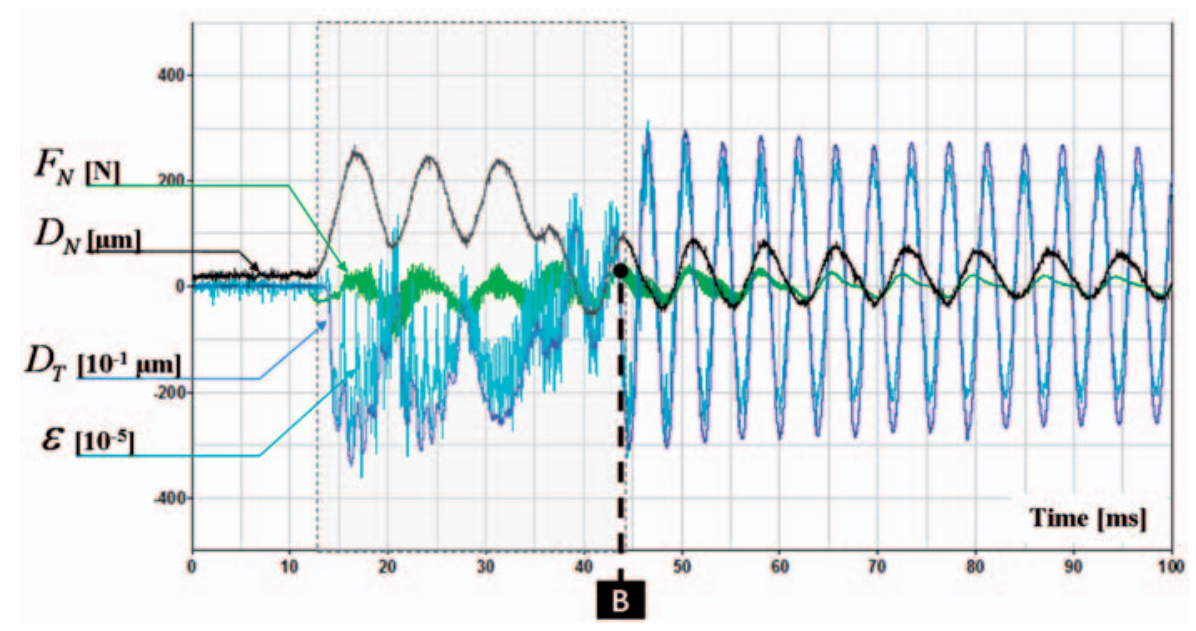

Figure 19. Experiment 7 (blade b; $V_{P}=10 \mathrm{~m} / \mathrm{s} ; D_{N}^{\max }=200 \mu \mathrm{m}$; and $V_{N}=60 \mathrm{~mm} / \mathrm{s}$ ) measurements.

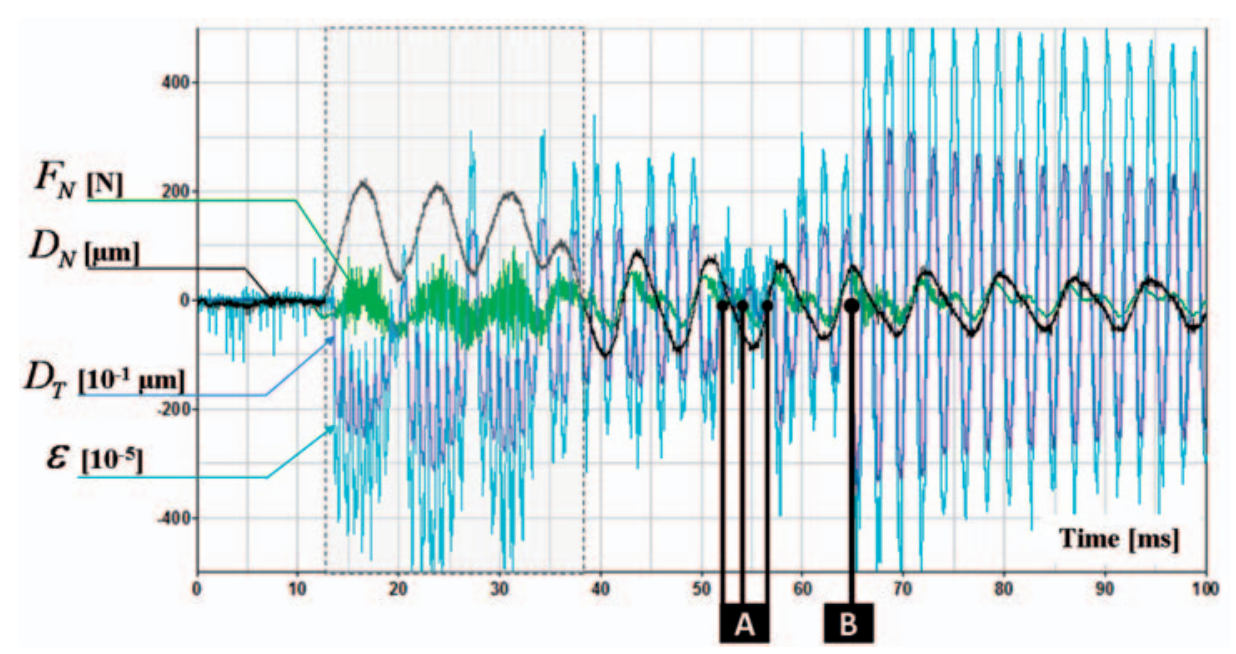

Figure 20. Experiment 8 (blade c; $V_{P}=19 \mathrm{~m} / \mathrm{s} ; D_{N}^{\max }=200 \mu \mathrm{m}$; and $V_{N}=60 \mathrm{~mm} / \mathrm{s}$ ) measurements.

\section{Experimental results summary}

Analysis of the experimental data provided an insight into which parameters do have an influence on blade excitation and track wear, and on how track wear affects blade excitation, in particular:

1. Increasing the depth and/or speed of apparent incursion has a detrimental influence on the amplitude of blade deflection at the seal contact, and it participates in multiplying the number of blade bounces on the seal during the blade/seal interaction.

2. Wearing of the abradable seal creates a surface roughness that activates and feeds blade excitation, resulting in high blade deflection amplitudes and bouncing frequencies.
The latter result is consistent with post-mortem observation done on a scale 1 compressor stage at SNECMA: fatigue cracks at blade roots were reported in correlation with an abradable track of the casing seal that was excessively worn, in a lobelike pattern, showing that blade vibrations had an impact on the wear pattern and conversely.

Also, the experiments described in this article showed that blade deflection amplitudes and bouncing frequencies can be significantly increased during the experiment as a result of a dynamic coupling at the blade/seal incursion. The unwanted coupling scenario is when the blade touches the seal with a speed that has the same direction as the relative blade/seal sliding speed. In a jet engine compressor, this phenomenon can participate to blade fatigue loading and premature wear of the abradable track. 


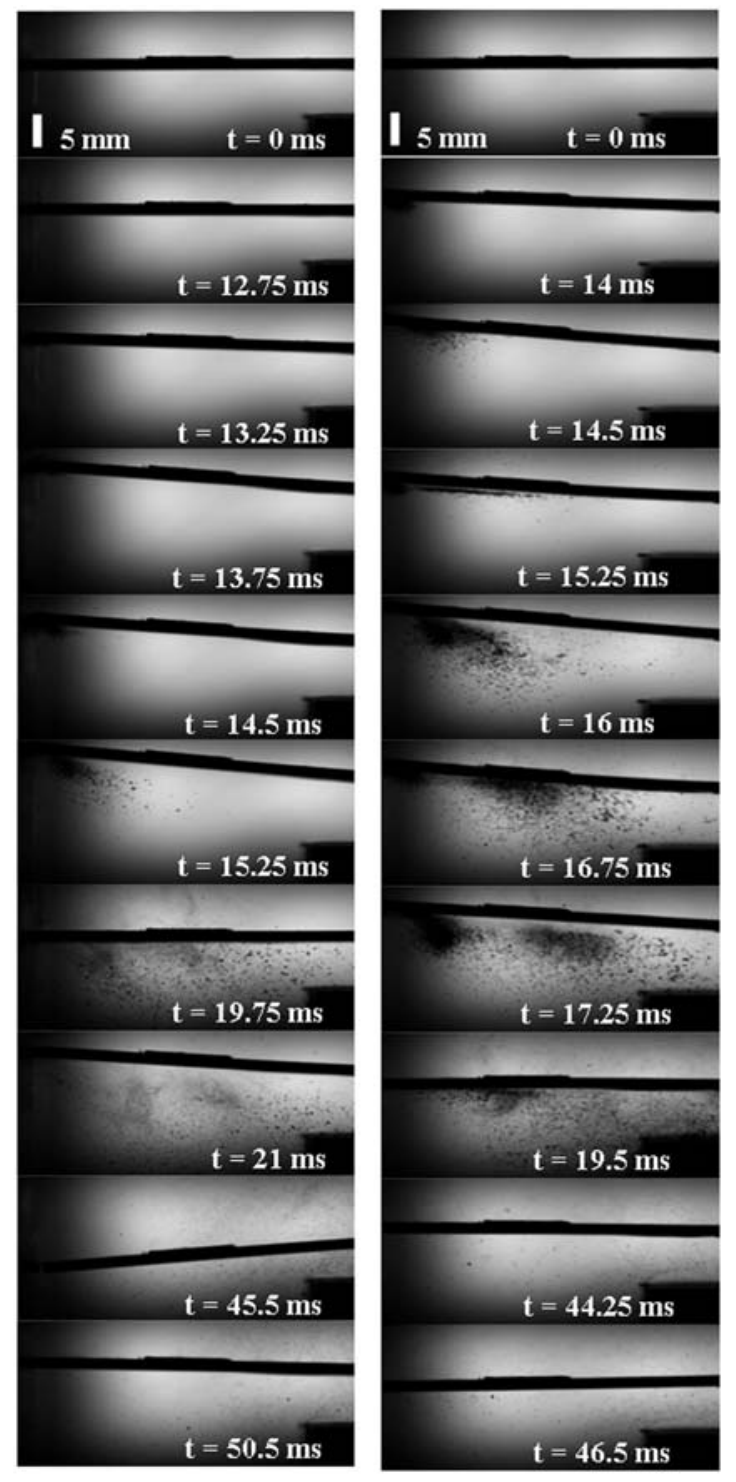

Figure 2I. High-speed video excerpts of experiments 2 (left) and 3 (right).

\section{Future developments}

The next step is to perform the same experiments at higher temperatures - up to $300^{\circ} \mathrm{C}$ - so that the mechanical and tribological properties of the abradable seal are representative of in-service conditions. Seal wear mechanism will then need to be identified through sampling and scanning electron microscopy (SEM) imaging of the coated tracks after testing.

To serve these purposes, the test rig needs to be improved, in particular:

(a) an actuator power that makes quicker strokes possible;

(b) an incursion cell with a higher rigidity in the normal direction, to impose more severe normal seal penetration and blade loading;

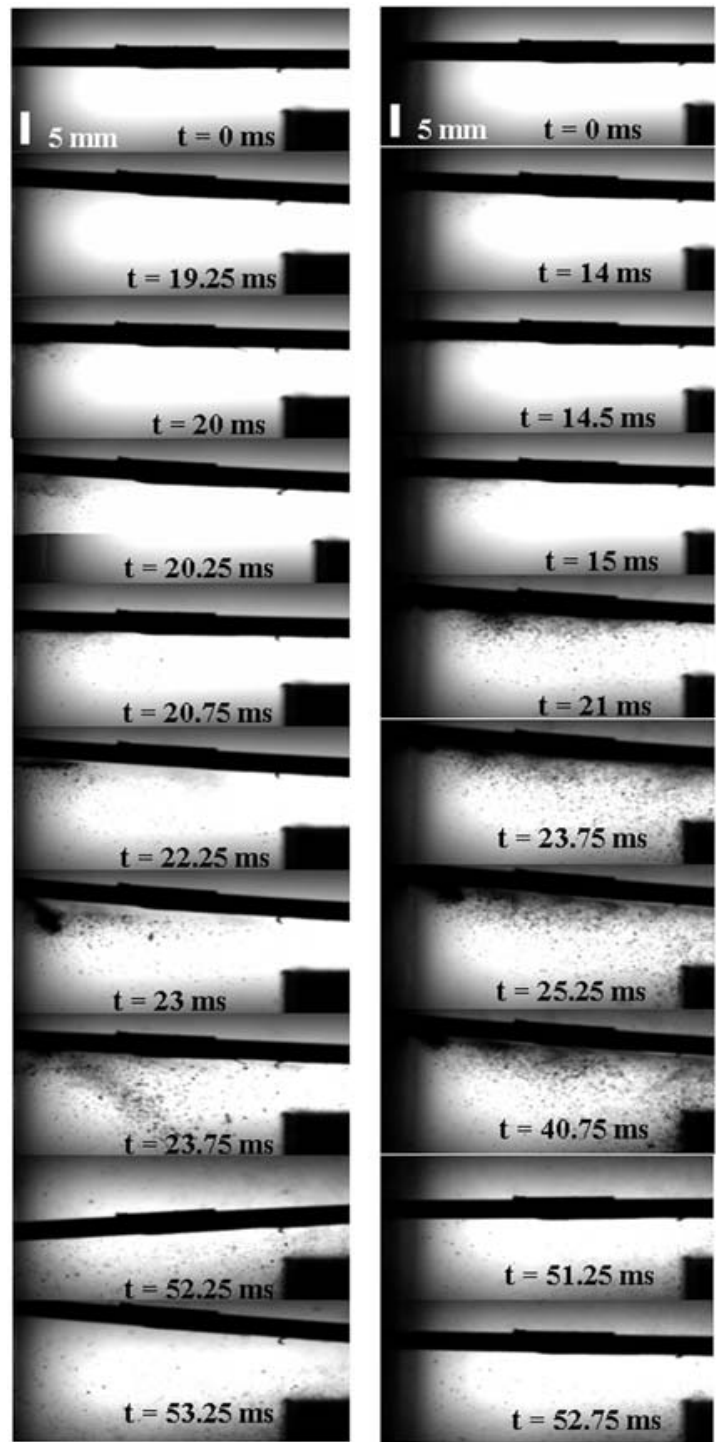

Figure 22. High-speed video excerpts of experiments 4 (left) and 5 (right).

(c) a cylinder's motorisation that allows testing rotation speeds of up to $100 \mathrm{~m} / \mathrm{s}$, and also, that guaranties a constant rotation for surface profile measurement at low speed before and after testing;

(d) a contact thermocouple, welded as close as possible to the blade tip to capture temperature rises during blade/seal rubs; and

(e) inductive components for heating the interaction zone at in-service temperatures.

Another required step is testing and modelling the mechanical and tribological behaviour of the abradable seal material behaviour at high temperatures and strain rates. Modelling the incursion cell will allow to extract the different components of the measured blade/seal interaction force, characterise the seal behaviour in the appropriate loading type and strain rate range. 


\section{Conclusions}

The experimental test rig described in this article has the capacity to reproduce blade/seal interactions with enough representativeness of in-service loading and speed to provide information on some of the dynamic couplings phenomena that can occur at the blade/seal interaction. These phenomena, both in the form of high amplitude of blade vibration or excessive wear of the abradable seal, can be highly detrimental to blade and seal performance. This is the reason why accurate numerical modelling of the rotor/stator dynamic interaction should take into account the presence of the abradable seal.

This rig allows the testing of key parameters, such as depth and speed of relative blade/seal penetration, relative blade seal sliding velocity, the number of blade/seal contacts, blade geometry and material as well as seal material and wear state. It was found that the most severe blade deflection amplitudes and bouncing frequencies at the blade/seal interaction occurred when the seal surface was previously worn, or for higher depths and speeds of blade penetration in the seal, which in turn increased seal wear. Moreover, the existence of a dynamical coupling between blade/seal sliding speed velocity and blade velocity that increased blade excitation was found. Since such phenomenon can decrease the blade and/ or seal in-service life, it is important that they be accounted for in numerical models.

Improvements of this prototype blade/seal interaction rig need to be done in order to extend its range of testing and measuring capabilities. In particular, the correction the motorisation instability in order to reach higher rotational speeds; the implementation of a more powerful actuator to generate incursions of greater depths at the required speed; the installation of induction components at the blade/ seal interaction zone to perform heated experiments at in-service temperatures; and the choice of a better instrumentation solution for the temperature measurement at the blade tip.

Future developments of this study include a thorough exploration of abradable wear mechanisms through micrographic inspection of the rubbed cylinder tracks after testing, and utilisation of the dynamic blade loading database for fatigue testing and simulation.

\section{Funding}

The authors gratefully acknowledge ONERA and Ecole Centrale de Lille for their support. This study took place in the framework of the MAIA mechanical research and technology program sponsored by CNRS, ONERA and $S A F R A N$. This study was also supported by International Campus on Safety and Intermodality in Transportation (CISIT), the Nord-Pas-de-Calais Region, the European Community, the Regional Delegation for Research and Technology, the Ministry of Higher Education and
Research, The French Ministry of Defense (through DGA grants) and the National Center for Scientific Research (CNRS). The authors gratefully acknowledge the support of these institutions.

\section{Acknowledgements}

The authors particularly thank Olivier Landemarre (LERMPS, UTBM) for his contribution in the fabrication of the abradable seal, and Julien Sergeant (ESCIL), for his help with the preparation of metallographic abradable samples.

\section{References}

1. Bounazef J, Djeffal A and Serier M. Optimisation by behaviour modelling of a protective porous material. Comput Mater Sci 2009; 44: 921-928.

2. DeMasi-Marcin JT and Gupta DK. Protective coatings in the gas turbine engine. Surf Coat Technol 1994; 68: $1-9$.

3. Faraoun HI, Seichepine JL, Coddet C, et al. Modelling route for abradable coatings. Surf Coat Technol 2006; 200: 6578-6582.

4. Chandler P. Abradable seal coatings and claddings for compressor applications. CA Technology Technical Report. FP5 GRD1-2001-40124, 2001. Islandia, NY: CA Technology Ltd.

5. Sulzer Metco. Thermal spray materials guide, 2010, p.19.

6. Hendricks R, Steinetz B and Braun M. Turbomachine sealing and secondary flows (I). NASA Technical Report, 2004. Washington, DC: NASA.

7. Chupp RE, Hendricks RC, Lattime SB and Steinet A. Turbomachinery clearance controls. Turbine Science and Technology, AIAA Progress in Astronautics and Aeronautics Series, 2007.

8. Matejicek J, Kolman B, Dubsky J, et al. Alternative methods for determination of composition and porosity in abradable materials. Mater Charact 2006; 57: 17-29.

9. Yi M, He J, Huang B and Zhou H. Friction and wear behaviour and abradability of abradable seal coating. Wear 1999; 234: 47-53.

10. Li S. Mécanismes d'endommagement des matériaux abradables à base MCrAlY pour turbines. $J$ Phys 2000; IV-10: 113-118.

11. ATSB. Engine Failure, Melbourne Airport, Boeing Company 777-312. Technical Report, ATSB, 2004.

12. Chappel D. Status of seal development at Technetics. NASA Seal and Secondary Air System Workshop, 2001. Washington, DC: NASA.

13. Bounazef M, Guessasma S and Adda Bedia EA. Blade protection and efficiency preservation of a turbine by a sacrificial material coating. Adv Powder Technol 2007; II-18: 123-133.

14. Emery AF, Wolak J, Etemad S and Choi SR. An experimental investigation of temperatures due to rubbing at the blade-seal interface in an aircraft compressor. Wear 1983; 91: 117-130.

15. Wang H. Criteria for analysis of abradable coatings. Surf Coat Technol 1996; 79: 71-75. 
16. ASTM:2005. Standard test methods for Rockwell hardness and Rockwell superficial hardness of metallic materials.

17. Peyraut F, Seichepine JL, Faraoun HI, et al. Simulation multi-physique et multi-échelle du comportement des revêtements abradables: application à l'Industrie aéronautique. In: AIP-PRIMECA 10th French national conference, La Plagne, France, 17-20 April 2007.

18. Ma X and Matthews A. Investigation of abradable seal coating performance using scratch testing. Surf Coat Technol 2007; 202: 1214-1220.

19. Ma X and Matthews A. Evaluation of abradable seal coating mechanical properties. Wear 2009; 267: $1501-1510$.
20. Borel MO, Nicoll AR, Schlapfer HW and Schmid RK. The wear mechanisms occurring in abradable seals of gas turbines. Surf Coat Technol 1989; 39-40: 117-126.

21. Lim S. Recent developments in wear mechanism maps. Tribol Int 1998; I/III-31: 87-97.

22. Bounazef M, Djeffal A, Serier M and Adda Bedia EA. Optimisation by behaviour modelling of a protective porous material. Comput Mater Sci 2009; 44: 921-928.

23. Sutter G, Philippon S and Garcin F. Dynamic analysis of the interaction between an abradable material and a titanium alloy. Wear 2006; 261: 686-692.

24. Johnston RE and Evans WJ. Freestanding abradable coating manufacture and tensile test development. Surf Coat Technol 2007; 202: 725-729. 